\title{
TINJAUAN USAHA KRUPUK KEMPLANG IKAN BILIK DESA LUMPATAN KECAMATAN SEKAYU
}

\author{
Wani Fitriah'1), Omar Hendro²) \\ 1),2) Fakultas Ekonomi dan Bisnis (FEB), Universitas Muhammadiyah Palembang \\ Jl. Jendral A.Yani, 13 Ulu, Seberang Ulu II, 13 Ulu Palembang, Kode pos 30116 \\ Email : wanifitriahump@yahoo.co.id ${ }^{11}$, omarhendro@ymail.com $^{2)}$
}

\begin{abstract}
ABSTRAK
Desa Lumpatan Sekayu memiliki sumberdaya perikanan yang cukup banyak. Pengembangan Industri hasil perikanan merupakan salah satu andalan masyarakat Desa Lumpatan. Industri pengolahan ikan yang potensial adalah industri pengolahan kerupuk ikan bilik, yang ditandai dengan adanya peningkatan jumlah unit usaha dalam setiap tahunnya. Industri pengolahan ikan yang memiliki produksi paling tinggi adalah produksi pengolahan kerupuk ikan bilik. Salah salah satu desa yang merupakan sentra industri pengolahan kerupuk ikan bilik adalah Desa Lumpatan. Kelompok industri rumah tangga ini merupakan usaha yang mengolah kerupuk ikan cilik dengan jumlah produksi terbesar di Sekayu. Kelompok industri usaha ini masih memakai teknologi rendah. Satu sisi produksi harus dingkatkan produksinya agar dapat memenuhi permintaan pasar. Oleh karena itu, perlu dilakukan analisis kelayakan usaha untuk meningkatkan pendapatan dan pemasaran. Penelitian ini menggunakan Analisis lingkungan internal dan eksternal, aspek finansial dan non finansial meliputi analisis aspek pasar, aspek teknis, aspek manajemen dan hukum, aspek sosial-ekonomi-budaya, dan aspek lingkungan.
\end{abstract}

Kata Kunci : Kelompok Usaha, Pengolahan Pemasaran serta Pendapatan.

\section{Pendahuluan}

Industri kecil adalah kegiatan industri yang dikerjakan di rumah-rumah penduduk yang pekerjanya merupakan anggota keluarga sendiri yang tidak terikat jam kerja dan tempat. Industri kecil dapat juga diartikan sebagai usaha produktif diluar usaha pertanian, baik itu merupakan mata pencaharian utama maupun sampingan (Tambunan, 2010). Pengembangan Industri hasil perikanan merupakan salah satu prioritas dalam pembangunan nasional di sektor perindustrian. Industri pengolahan hasil perikanan merupakan salah satu bagian dari agroindustri yang sangat berpeluang memilki daya saing kuat dan bertahan dalam jangka waktu yang lama. Agroindustri hasil perikanan yang sudah berkembang baik dalam skalabesar/menengah maupun skala kecil adalah industri pengolahan ikan, pembekuan ikan, pengolahan tepung ikan, penggaraman ikan, pengasapan ikan, pengolahan kerupuk ikan, serta pengolahan dan pengawetan ikan lainnya. Pengolahan pada hakikatnya mempunyai fungsi untuk memaksimumkan manfaat hasil tangkapan, meningkatkan nilai tambah ekonomi dan memperpanjang daya tahan simpanan, serta mendiversifikasikan kegiatan dan komoditas yang dihasilkan sehingga sangat berpengaruh terhadap keadaan social ekonomi nelayan. Dalam posisinya pada sembilan bahan pokok, olahan ikan juga berperan sangat besar dalam masalah gizi dan kesehatan masyarakat.

Usaha kreatif adalah program pemerintah yang bertujuan agar masyarakat mampu untuk hidup lebih sejahtera. Usaha kecil dan menengah, harus mendapat perhatian khusus dari pemerintah. Perhatian tersebut melalui program yang berkesinambungan, tidak hanya berjangka pendek dan terputus. Maksudnya mulai dari tahapan input, proses dan output, sampai ke proses pemasaran dan penyusunan laporan keuangan.

Perlindungan usaha kecil di Indonesia diatur dalam Undang Undang Republik Indonsia Nomor 9 Tahun 1995 tentang usaha kecil. Sebagai pelaksanaan undangundang tersebut telah dikeluarkan Peraturan Pemerintah Republik Indonesia Nomor 44 Tahun 1997 tentang kemitraan. Masyarakat yang mempunyai usaha kreatif, berupaya melakukan pengembangan usaha kecilnya sehingga usaha kecil itu mampu menjadi usaha yang tangguh dan mandiri. Peranan pengembangan produk sangatlah penting, adanya perubahan yang cepat dalam selera dan persaingan, menyebabkan perusahaan dituntut untuk mampu bersaing dan menciptakan produk yang sesuai dengan keinginan dan 
kebutuhan konsumen. Keinginan dan kebutuhan konsumen merupakan sumber yang paling utama dalam proses pengembangan produk karena keinginan konsumen terhadap produk yang ditawarkan di pasar selalu berubah. Keinginan konsumen selalu dan selalu berubah-ubah menurut para manajemen pemasaran untuk terus aktif dan melakukan pemantauan terhadap jenis produk yang bagaimana sedang digemari oleh konsumen.

Salah satu usaha yang sudah cukup lama dan berpotensi saat ini adalah industri krupuk kemplang ikan bilik di Desa Lumpatan Sekayu. Usaha ini dapat dikatakan memiliki prospek yang cukup baik dimana kebutuhan masyarakat semangkin meningkat. Usaha kupuk kemplang ini merupakan salah satu usaha yang bergerak dibidang industri kecil dan menengah. Dikatakan usaha kecil, kerena beberapa pengelolah masih berskala kecil. Baik dari segi permodalan, produksi dan pemasarannya. Sedangkan usaha sudah menengah, permodalan sudah ditingkat menengah, begitupun dengan hasil produksi dan pemasarannya.

Usaha krupuk kemplang ikan bilik Desa Lumpatan Sekayu ini mengelolah produknya secara massa. Secara massa karena pekerja-pekerjanya secara tolong menolong dari masyarakat sekitar. Bahan baku utamanya adalah sagu atau tepung tapioka dan ikan bilik. Namun untuk bahan baku ikan bilik, yang tadinya ikan-ikan kecil sungai, karena ketersediaan dan harganya yang tidak stabil, maka digantikan kepala ikan teri. Kepala ikan teri ini ketersediaan sealu mudah didapat dan harganya juga lebih murah.

Para pengelolah krupuk kemplang ikan bilik di Desa Lumpatan Sekayu ini berusaha untuk mempertahankan dan meningkatkan hasil produksinya. Namun karena kurangnya penyuluhan dan pembinaan terhadap usaha ini, tingkat keuntungan mereka, yaitu dengan cara mengembangkan produk. Hal ini menuntut usaha ini untuk melakukan pengembangan yang tepat dikarenakan pada saat ini persaingan semangkit ketat. Apabila usaha kurang efektif dalam upaya pengembangan, bukan tidak mungkin usaha ini tidak dapat bertahan. Agar usaha ini dapat bertahan maka harus melakukan perbaikan permodalan, produksi, pengembangan produk yang baik dan pemasaran yang efektif. Pemasaran meliputi keseluruhan sistem yang berhubungan dengan kegiatan-kegiatan usaha, yang bertujuan merencanakan, menentukan harga, hingga mempromosikan dan mendistribusikan barangbarang atau jasa yang akan memuaskan kebutuhan pembeli, baik yang aktual maupun yang potensial (Sofyan A, 2002:17).

\subsection{Tujuan Pengadian}

a. Pembuat/penjual :

1. Mengetahui standarisasi faktor lingkungan internal dan eksternal.

2. Mengetahui strategi segmentasi pasar,pengembangan/inovasi krupuk kemplang di Desa Lumpatan Sekayu.

b. Pembeli/konsumen :

1. Mengetahui tanggapan konsumen terhadap produk, dan lokasi penjualan.

2. Mengetahui keefektifan promosi dan keputusan pembelian oleh konsumen krupuk kemplang Desa Lumpatan Sekayu.

\subsection{Manfaat Pengabdian}

a. Pengelolah/pembuat atau penjual.

Pengelolah/pembuat ataupun penjual pertama, mempunyai standar dalam membuat/ memproduksi krupuk kemplang. Kedua, meningkatkan kualitas dan kuantitas produksinya. Ketiga, keuntungannya akan semakin meningkat sehingga pembuat dan para pekerjanya menerima pendapatannya sesuai dengan harapan.

b. Pembeli/konsumen.

Pembeli/konsumen pertama, terpenuhinya selera, kualitas sesuai keinginan dan ketersediaan krupuk kemplang (kuantitas) di warung/toko. Kedua, terpenuhinya kepuasan pembeli/konsumen, sehingga keputusan untuk membeli krupuk kemplang akan terus berlanjut (terciptanya pelanggan).

c. Pemerintah.

Berjalannya program peningkatan usaha kecil dan menengah yang kreatif dan inovatif untuk mensejahterakan masyarakat pedesaan. 


\section{METODE PELAKSANAAN PENGABDIAN}

Pelaksanan pengabdian dengan menguraikan tentang tahapan pelaksanaan pengabdian dalam menyelesaikan persoalan di Usaha krupuk kemplang. Adapaun tahapan kegiatan pengabdian dan penjelasannya dijelaskan pada sub bab berikut ini.

\subsection{Tahapan Pengabdian}

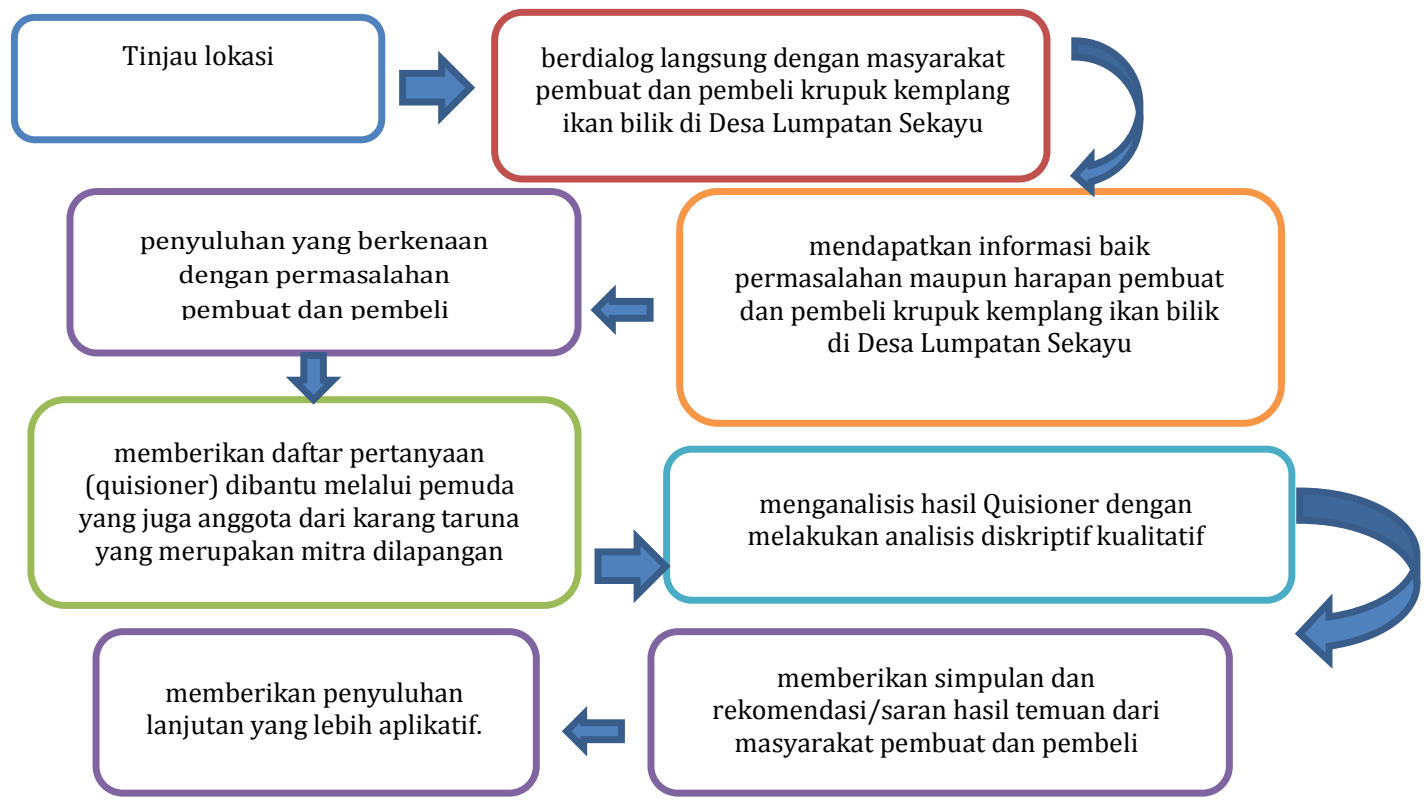

Gambar 1. Tahapan pelaksanaan Pengabdian

\subsection{Analisa dan Solusi Permasalah Usaha Krupuk Kemplang}

Solusi yang ditawarkan adalah pertama, harus adanya dukungan faktor internal dan eksternal. Kedua, strategi segmentasi pasar dan pasar terpusat krupuk kemplang harus menjadi rencana. Ketiga, melakukan pengembangan atau inovasi krupuk kemplang. Keempat, pembuat krupuk kemplang harus menjalankan bauran pemasaran, untuk meningkatkan keputusan pembelian konsumen, sehingga meningkatkan volume produksi dan penjualan.

\subsection{Kesepakatan dengan Usaha Kerupuk Kemplang.}

Hasil pengabdian ini hendaknaya Pemilik Usaha krupuk kemplang, dapat menjaga standarisasi pengolahan krupuk kemplang agar kualitas tidak berubah sehingga memuaskan konsumen. Kedua, pengelolah harus selalu membuat persediaan, agar kuantitas ketersediaan krupuk kemplang selalu ada. Ketiga, pengelolah dan pendistribusi hendaknya aktif mencari pasar baru untuk memperluas daerah pemasaran. Keempat, pengelolah harus lebih memperhatikan keluhan-keluhan pelanggan untuk peningkatan kualitas dan kuantitas. Kelima, pengusaha krupuk kemplang menjaga hubungan yang selalu baik dengan tenaga kerja dengan memperhatikan tingkat upah mereka. Keenam pengelolah bersedia untuk mengikuti dan melaksanakan masukkan dari penyuluh. Jika ada program bantuan modal dari pemerintah, harus mampu mengembalikan pinjaman tersebut pada waktu tertentu.

\subsection{Persiapan Pelaksanaan}

Persiapan Aktifitas Produksi ;

a. Bahan baku

Bahan baku utama dalam pembuatan krupuk kemplang ini adalah ikan dan tepung tapioca (sagu) yang dibeli dari pasar tradisional Kota Sekayu. Karena ketersediaan dan harga ikan sungai bilik (kecil) tidak stabil (kadang ada, kadang tidak), maka pengganti ikan bilik ini adalah kepala atau remah ikan teri. Bahan ini ketersediaannya mudah didapat dan harga cukup stabil. 
b. Proses produksi

Proses produksi adalah suatu cara, metode atau teknik yang digunakan untuk menciptakan atau menambah kegunaan sumber yang ada. Usaha krupuk kemplang akan melakukan proses produksi terlebih dahulu, dengan cara memproses bahan baku menjadi krupuk kemplang melalui pengelolaan yang dilakukan para pekerja.

Tahap-tahap proses pembuatan sebagai berikut :

1) Persiapan bahan

Pada tahap ini dilakukan persiapan dan bahan yang telah ditentukan berapa banyak ikan bilik dan tepung tapioka yang akan diperlukan untuk satu kali olah ( satu hari). Misal, $3 \mathrm{~kg} \mathrm{sagu,} 1 \mathrm{~kg}$ sari teri (teri yang sudah diblender, diambil airnya).

2) Proses pengerjaan

Proses pengerjaan pembuatan krupuk kemplang ini terbagi 2 (dua) sesi. Sesi pertama yaitu jam 08.00 - 12.00 WIB, pembuatan pengadonan, sagu dan ikan. Sagu dan ikan yang sudah dicampur diuli sampai rata lalu dipirik (cetakan krupuk) menjadi bentuk krupuk yang siap dikukus. Setelah dikukus maka ditiris dan disusun di tampa untuk dikeringkan di cahaya matahari. Ibu-ibu (mayoritas) akan pulang ke rumah untuk mengurus rumah tangganya. Pada sesi ini juga dibarengin dengan menggoreng krupuk yang sudah cukup kering, yang dijemur di hari sebelumnya.

3) Sesi kedua yaitu jam 15.30 - 18.00 WIB memeriksa atau membalik krupuk yang dijemur agar keringnya rata. Karena rumah pekerja berdekatan dengan rumah produksi, jika cuaca buruk (hujan) mereka serta merta menyelamatkan jemuran krupuk tadi agar tidak kehujanan. Jika cuaca baik, jam 17.30 mereka mengumpulkan krupuk yang sudah kering tadi di satu tempat (bakul besar dari rotan). Inilah aktivitas keseharian yang dilakukan pengelolah krupuk kemplang Desa Lumpatan.
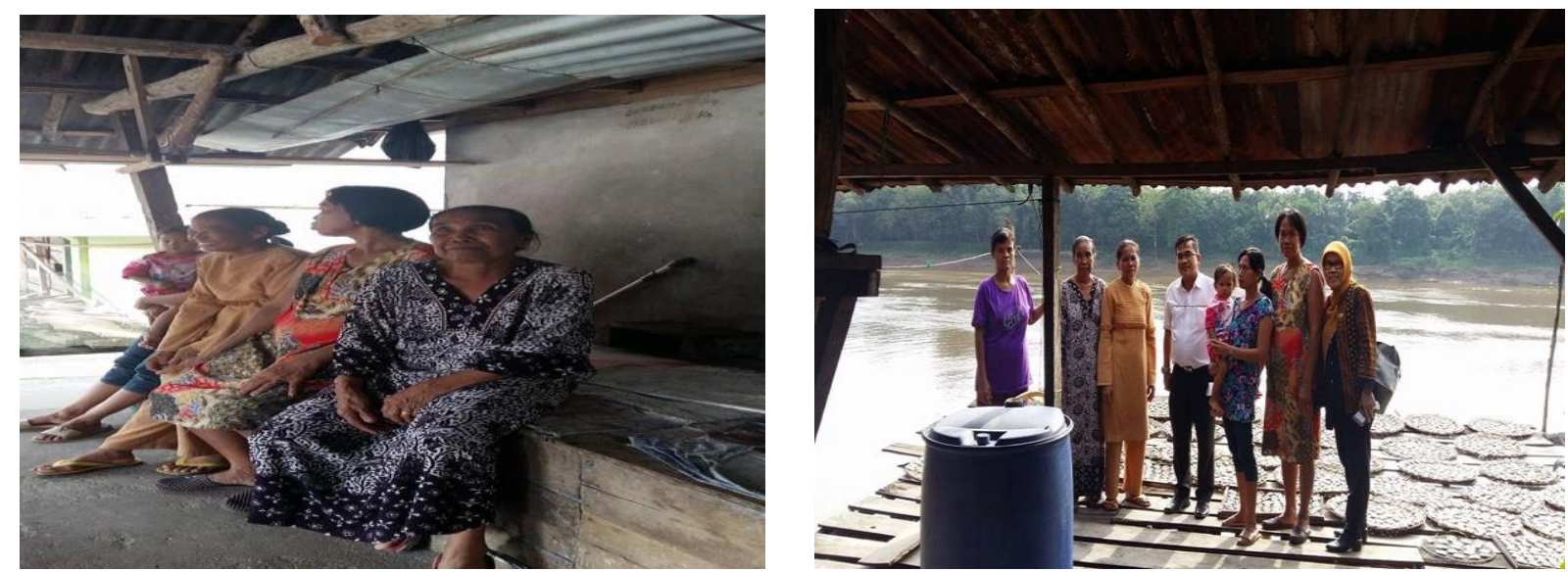

Gambar 2. Pengeringan krupuk kemplang oleh pekerja.

4) Proses pembungkusan Krupuk kemplang.

Proses pembungkusan krupuk kemplang ini, kedalam plastik-plastik besar. Isi satu plastik ini 30-35 krupuk yang dijual kepada si pendistribusi seharga lebih kurang Rp. 8.000-Rp.10.000,- perbungkus.

5) Proses pendistribusian/penjualan Krupuk kemplang.

Proses pendistribusian, si pengumpul mendatangi rumah pengelolah krupuk kemplang. Pendistribusi ini menjual ke warung-warung seharga Rp.12.000-Rp.13.000,-.sedangkan warungwarung akan menjual kepembeli Rp. 500- Rp.1.000,- 

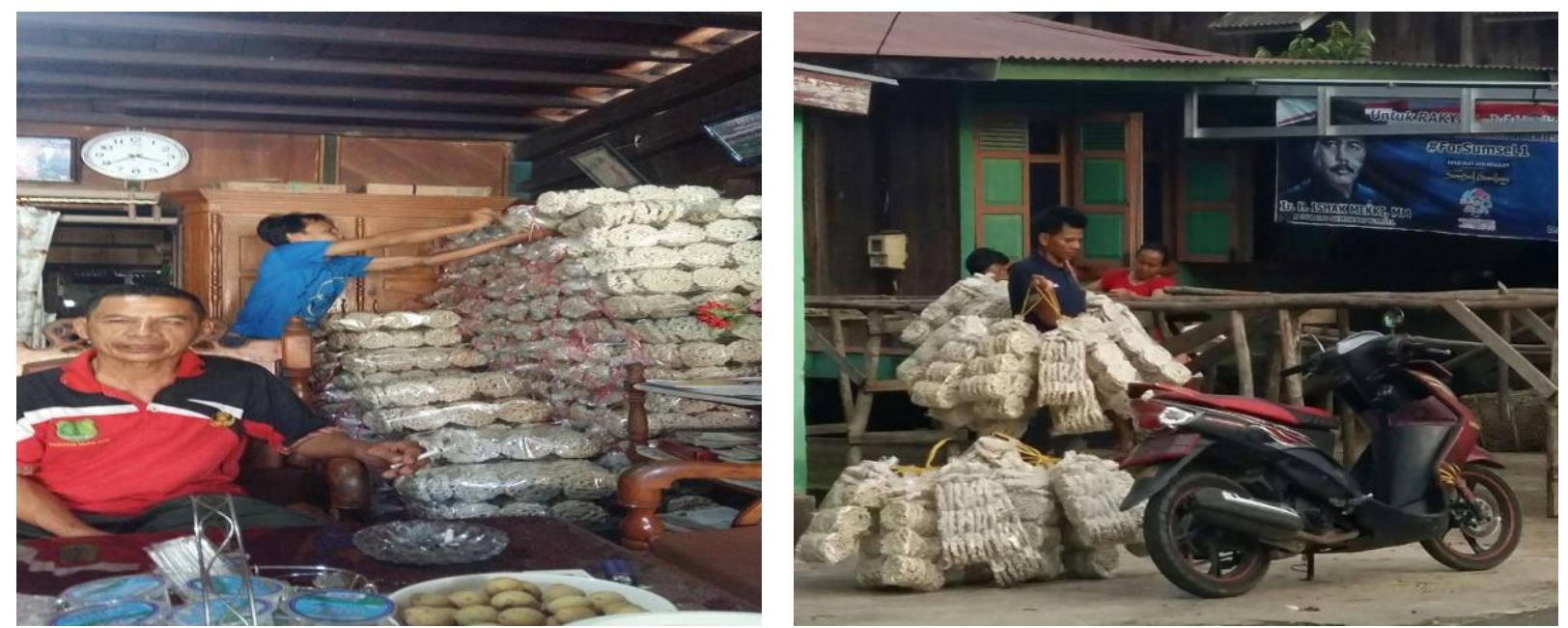

Gambar 3. Pembungkusan dan Pendistribusian krupuk kemplang.

\subsection{Pelaksanaan Pengabdian}

Pelaksanan pengabdian dimulai dari pertama, peninjauan lokasi usaha krupuk kemplang. Kedua, berdialog langsung kepada pemilik usaha dan pembeli krupuk kemplang. Ketiga, memberikan masukkan dari permasahan yang mereka hadapi. Keempat. bersama mitra memberikan kuisioner kepada pembuat dan pembeli, untuk mendapatkan data. Kelima, menganalisis data tersebut secara kualitatif dan kuantitatif (analisis statistik). Keenam, membuat simpulan dari analisis data tersebut. Ketujuh, memberikan penyuluhan yang aplikatif bagi pengelolah krupuk kemplang agar adanya perbaikan standar kualitas, pemasaran dan peningkatan volume penjualan dan keuntungan bagi pengelolah dan pekerja usaha krupuk kemplang Desa Lumpatan.

\subsection{Evaluasi kegiatan}

Usaha krupuk kemplang ini awalnya penopang dari pendapatan kebun karet masyarakat Desa Lumpatan di tahun 1995an. Namun seiring akibat dari krisis ekonomi di tahun 1997-1998 pengusaha krupuk kempalng ini mengalami peningkatan. Hingga tahun 2017an pengusaha ini masih eksis, dengan naik turunya pendapatan mereka.

Pengusaha krupuk kemplang ini mempekerjakan masyarakat sekitar tempat produksi, umunya para ibu-ibu. Pekerjaan ini mengisi waktu luang ibu-ibu setelah mengurus rumah tangga. Pendapatan yang mereka terima (besar-kecilnya)terkadang tidak menjadi tuntutan mereka. Setiap rumah usaha ratarata mempekerjakan 5-10 ibu-ibu rumah tangga. Krupuk kemplang ini melalui penjajah/pengumpul dijual sampai ke pelosok-pelosok dusun. Jika cuaca baik (tidak musim penghujan) penjualan meningkat. Selain produksi lancar karena pengeringan tidak tertunda oleh hujan, jalan-jalan kepelosok desa tidak banjir/becek, sehingga pemasran oleh pengumpul tidak terhambat. Tetapi jika bertepatan dengan musim buah, maka masyarakat pengkonsumsi krupuk kemplang menurun. Karena mereka mengkonsumsi buah-buah musiman ini (duku, rambutan, tampui, durian dan lainnya).

\section{HASIL DAN PEMBAHASAN}

Berdasarkan analisis situasi dapat dirumuskan beberapa hasil analisis data sebagai berikut :

\subsection{Pembuat/penjual}

a. Faktor lingkungan internal : Standarisasi pengelolah krupuk kemplang.

Produk krupuk kemplang di Desa Lumpatan, belum terstandarisasi. Pertama, bentuk krupuk kemplang masih beragam besar kecilnya. Kedua, cetakan yang dipakai alatnya tradisional (pirikan), sehingga sangat tergantung dari pembuatnya. Ketiga, saat pengkukusan, suhu (panas) dan lama pengukusan (waktu) tidak terukur.

b. Apakah faktor lingkungan eksternal : dukungan terhadap pengelolah krupuk kemplang.

Pengelolah sangat mengharapkan sekali dukungan dari pemilik modal, perbankan dan pemerintah. Pemilik modal khususnya juga pengelolah produk ini, tidak mengkoordinir pengelolah-pengelolah lainnya yang masih seadanya dalam memproduksi krupuk kemplang ini (modal kecil). Perbankan tidak berani meminjamkan modalnya tanpa jaminan, dari si peminjam. Pada umumnya pengelolah ini tidak ada yang dapat dijaminkan. Pemerintah, belum mempunyai program yang efektif terhadap 
kemajuan usaha krupuk kemplang ini. Kalaulah ada bantuan, itu hanya sebatas penyuluhan, mereka diundang ke kantor pemerintah terkait (Depperindag Kabupaten MUBA)

c. Strategi segmentasi pasar dan pasar terpusat krupuk kemplang.

Masih berskala usaha rumah tangga (home industry), usaha mikro kecil yang mempunyai buruh/karyawan kurang dari 20 orang (BPS RI). Sehingga kalau dibuat pasar terpusat untuk produk ini, masih kurangnya (tidak stabil) pasokan untuk pembeli.

d. Pengembangan atau inovasi krupuk kemplang.

Pengembangan produk dan inovasi belum dilakukan, bentuk belum berani mereka ubah. Bentuk krupuk kemplangnya masih sangat konvensional. Inovasi tidak dilakukan, dikarenakan takut konsumen tidak mau membelinya.

\subsection{Pembeli/konsumen :}

a. Uji Regresi.

Analisis regresi linier berganda digunakan dalam penelitian ini dengan tujuan untuk membuktikan hipotesis mengenai pengaruh Variabel Harga $\left(X_{1}\right)$, Produk $\left(X_{2}\right)$, Tempat $\left(X_{3}\right)$ dan Promosi $\left(\mathrm{X}_{4}\right)$ terhadap Keputusan Pembelian (Y). Perhitungan statistik dalam analisis regresi linier berganda yang digunakan dalam penelitian ini adalah dengan menggunakan bantuan program komputer SPSS For Windows Relase 15.00. Hasil pengolahan datanya:

Tabel 1. Hasil Koefisien Regresi Berganda

Coefficients

\begin{tabular}{|ll|r|r|r|r|r|}
\hline \multirow{2}{*}{ Model } & \multicolumn{2}{|c|}{$\begin{array}{l}\text { Unstandardized } \\
\text { Coefficients }\end{array}$} & \multicolumn{2}{c|}{$\begin{array}{c}\text { Standardized } \\
\text { Coefficients }\end{array}$} & \\
\cline { 3 - 5 } & & \multicolumn{1}{|c|}{ B } & Std. Error & \multicolumn{1}{c|}{ Beta } & \multicolumn{1}{c|}{$\mathrm{t}$} & \multicolumn{1}{c|}{ Sig. } \\
\hline 1 & (Constant) & -1.040 & .574 & & -1.813 & .082 \\
& Harga & .289 & .118 & .282 & 2.452 & .022 \\
& Produk & .345 & .088 & .445 & 3.920 & .001 \\
& Tempat & .342 & .098 & .431 & 3.494 & .002 \\
& Promosi & .285 & .104 & .352 & 2.741 & .011 \\
\hline
\end{tabular}

a. Dependent Variable: Keputusan Pembelian

Sumber : Hasil olah data primer

Berdasarkan tabel 1 diatas maka didapat persamaan regresi berganda sebagai berikut:

$$
Y=-1,040+0,289 X_{1}+0,345 X_{2}+0,342 X_{3}+0,285 X_{4}
$$

Intepretasi dari persamaan regresi berganda mengenai pengaruh Variabel Harga $\left(\mathrm{X}_{1}\right)$, Produk $\left(\mathrm{X}_{2}\right)$, Tempat $\left(\mathrm{X}_{3}\right)$ dan Promosi $\left(\mathrm{X}_{4}\right)$ terhadap Keputusan Pembelian $(\mathrm{Y})$ dapat dijelaskan sebagai berikut:

a. Nilai konstanta sebesar $-1,040$ menunjukkan bahwa jika Variabel Harga $\left(\mathrm{X}_{1}\right)$, Produk $\left(\mathrm{X}_{2}\right)$, Tempat $\left(\mathrm{X}_{3}\right)$ dan Promosi $\left(\mathrm{X}_{4}\right)$ dianggap tidak ada (nol) maka Variabel Keputusan Pembelian (Y) sebesar $10,492$.

b. Harga $\left(X_{1}\right)$ sebesar 0,289 berslope positif, hal ini menyatakan bahwa jika persepsi konsumen tentang Harga mengalami peningkatan sebesar 1 satuan, maka Keputusan Pembelian (Y) akan mengalami peningkatan sebesar 0,289 .

c. Produk $\left(\mathrm{X}_{2}\right)$ sebesar 0,345 berslope positif, hal ini menyatakan bahwa jika Kualitas Produk mengalami kenaikan sebesar 1 satuan, maka Keputusan Pembelian (Y) akan mengalami peningkatan sebesar 0,345 .

d. Tempat/Distribusi $\left(\mathrm{X}_{3}\right)$ sebesar 0,342 berslope positif, hal ini menyatakan bahwa jika Tempat mengalami kenaikan sebesar 1 satuan, maka Keputusan Pembelian (Y) akan mengalami peningkatan sebesar 0,342 .

e. Promosi $\left(\mathrm{X}_{4}\right)$ sebesar 0,285 berslope positif, hal ini menyatakan bahwa jika Kualitas Promosi mengalami kenaikan sebesar 1 satuan, maka Keputusan Pembelian (Y) akan mengalami peningkatan sebesar 0,285. 
f. Keempat koefisien variabel bebas berslope positif, hal ini menunjukkan hubungan linier positif (searah) antara Variabel Bebas terhadap Variabel Terikat artinya jika terjadi peningkatan/perbaikan pada item variabel bebas, maka akan semakin meningkat pula keputusan pembelian yang akan dilakukan oleh konsumen, hal berlaku sebaliknya.

b. Uji Korelasi dan Koefisien Determinasi.

1. Uji Korelasi (R).

Hasil koefisien korelasi dapat dijelaskan melalui tabel berikut ini :

Tabel 2. Hasil Uji Korelasi

\begin{tabular}{|l|r|r|r|r|r|}
\multicolumn{7}{c|}{ Model Summary } \\
\hline Model & $\mathrm{R}$ & $\mathrm{R}$ Square & $\begin{array}{c}\text { Adjusted } \\
\text { R Square }\end{array}$ & $\begin{array}{c}\text { Std. Error of } \\
\text { the Estimate }\end{array}$ & $\begin{array}{c}\text { Durbin- } \\
\text { Watson }\end{array}$ \\
\hline 1 & $.853^{\mathrm{a}}$ & .727 & .684 & .323425 & 1.475 \\
\hline
\end{tabular}

a. Predictors: (Constant), Promosi, Produk, Harga, Tempat

b. Dependent Variable: Keputusan Pembelian

Sumber : Hasil olah data primer

Koefisien korelasi (R) sebesar 0,853. artinya bahwa hubungan kedua variabel signifikan dan tingkat keeratannya Kuat. Interprestasi kolerasinya sebagai berikut :

Tabel 3. Pedoman Interprestasi Koefisien Kolerasi

\begin{tabular}{|c|c|}
\hline $\begin{array}{c}\text { Interval } \\
\text { Koefisien }\end{array}$ & $\begin{array}{c}\text { Tingkat } \\
\text { hubungan }\end{array}$ \\
\hline $0,00-0,199$ & Sangat Rendah \\
\hline $0,20-0,399$ & Rendah \\
\hline $0,40-0,599$ & Sedang \\
\hline $0,60-0,799$ & Kuat \\
\hline $0,80-1,000$ & Sangat Kuat \\
\hline \multicolumn{2}{|c|}{ Sumber: Sugiyono (2007:183) }
\end{tabular}

2. Uji Koefiien Korelasi ( $\left.\mathrm{R}^{2}\right)$.

Dari hasil estimasi data rekap jawaban responden, maka hasil Koefisien

Determinasi dapat dijelaskan melalui tabel berikut ini :

Tabel 4. Hasil Uji Koefisien Determinasi

Model Summary

\begin{tabular}{|l|r|r|r|r|r|}
\hline Model & $\mathrm{R}$ & $\mathrm{R}$ Square & $\begin{array}{c}\text { Adjusted } \\
\text { R Square }\end{array}$ & $\begin{array}{c}\text { Std. Error of } \\
\text { the Estimate }\end{array}$ & $\begin{array}{c}\text { Durbin- } \\
\text { Watson }\end{array}$ \\
\hline 1 & $.853^{\mathrm{a}}$ & .727 & .684 & .323425 & 1.475 \\
\hline
\end{tabular}

a. Predictors: (Constant), Promosi, Produk, Harga, Tempat

Sumber : Hasil olah data primer

Hasil perhitungan dengan penggunaan program SPSS For Windows Relase 15.00. diperoleh bahwa nilai $\mathrm{R}^{2}=0,727$ yang berarti bahwa Variabel Bebas mampu menjelaskan Variabel Terikat sebesar 0,727 atau $72,7 \%$, sedangkan sisanya sebesar $22,3 \%$ dijelaskan oleh faktor lain yang tidak diteliti. Dikarenakan nilai koefisien determinasi yang dinilai relative tinggi yaitu sebesar $72,7 \%$, maka dalam hal ini peneliti memberikan rekomendasi kepada peneliti yang lain untuk dapan melakukan penelitian serupa guna menyempurnakan penelitian ini dengan variabel lainnya diluar variabel yang sedang peneliti gunakan saat ini.

3. Uji Hipotesis. 
a. Uji t (t-test).

Uji t digunakan untuk menguji apakah terdapat pengaruh signifikasn antara Variabel Bebas terhadap Variabel Terikat. Untuk menentukan apakah hipotesis yang diajukan signifikan atau tidak, maka perlu dilihat dari estimasi t-hitung yang ditunjukan oleh tabel berikut ini :

Tabel 5. Hasil Uji Hipotesis (Uji t)

Coefficients

\begin{tabular}{|c|c|c|c|c|c|c|}
\hline \multirow{2}{*}{\multicolumn{2}{|c|}{ Model }} & \multicolumn{2}{|c|}{$\begin{array}{l}\text { Unstandardized } \\
\text { Coeff icients }\end{array}$} & \multirow{2}{*}{$\begin{array}{c}\text { Standardized } \\
\text { Coeff icients } \\
\text { Beta } \\
\end{array}$} & \multirow[b]{2}{*}{$t$} & \multirow[b]{2}{*}{ Sig. } \\
\hline & & $B$ & Std. Error & & & \\
\hline \multirow[t]{5}{*}{1} & (Constant) & -1.040 & .574 & & -1.813 & .082 \\
\hline & Harga & .289 & .118 & .282 & 2.452 & .022 \\
\hline & Produk & .345 & .088 & .445 & 3.920 & .001 \\
\hline & Tempat & .342 & .098 & .431 & 3.494 & .002 \\
\hline & Promosi & .285 & .104 & .352 & 2.741 & .011 \\
\hline
\end{tabular}

a. Dependent Variable: Keputusan Pembelian

Sumber : Data (diolah) SPSS

Berdasarkan tabel 5. dapat diketahui bahwa nilai thitung untuk Variabel Harga sebesar 2,452, Variabel Produk sebesar 3,920, Variabel Tempat sebesar 3,494 dan Variabel Promosi sebesar 2,741 jika dibandingkan dengan ttabel $=2,0595$. Hasil setimasi tersebut menyatakan bahwa nilai t-hitung keempat variabel bebas atas variabel terikat lebih besar dari t-tabel (thitung > ttabel), maka kreteria Ha diterima dan Ho ditolak, hal ini berarti keempat variabel bebas tersebut dapat dikatakan berpengaruh signifikan terhadap variabel terikat. Disisi lain, jika dibandingkan antara nilai koefisien Sig. dengan nilai P-value $(\alpha)$ sebesar 0,05, maka dapat diketahui bahwa koefisien Sig. variabel $\mathrm{X}_{1}$ sebesar 0,022, koefisien Sig. variabel $X_{2}$ sebesar 0,001, koefisien Sig. variabel $X_{3}$ sebesar 0,002 dan koefisien Sig. variabel $\mathrm{X}_{4}$ sebesar 0,011, keempat variabel bebas tersebut memiliki nilai koefisien Sig. yang masih dibawah nilai P-value $(\alpha)$ sebesar 0,05 , hal ini berarti Ha diterima dan H0 ditolak, artinya bahwa ada hubungan secara signifikan antara Variabel Bebas terhadap Variabel Terikat.

b. Uji F (F-test).

Hasil analisis data dengan menggunakan program SPSS For Windows Relase 15.00 dapat disajikan dalam tabel berikut:

Tabel 6. Hasil Estimasi uji F

ANOVA

\begin{tabular}{|c|c|c|c|c|c|c|}
\hline Model & & $\begin{array}{l}\text { Sum of } \\
\text { Squares }\end{array}$ & $d f$ & Mean Square & $F$ & Sig. \\
\hline \multirow[t]{3}{*}{1} & Regression & 6.977 & 4 & 1.744 & 16.675 & $.000^{\mathrm{a}}$ \\
\hline & Residual & 2.615 & 25 & .105 & & \\
\hline & Total & 9.592 & 29 & & & \\
\hline
\end{tabular}

a. Predictors: (Constant), Promosi, Harga, Produk, Tempat

b. Dependent Variable: Keputusan Pembelian

Sumber : Hasil olah data primer

Dari tabel 6. diketahui nilai Fhitung sebesar 16,675 > nilai Ftabel sebesar 2,7587 dan dikuatkan dengan nilai koefisien sig. Fhitung sebesar 0,000 < P-value $(\alpha)$ sebesar 0,05. Berdasarkan kriteria pengujiannya adalah jika nilai koefisien sig. $\mathrm{F}<\mathrm{P}$-value $(\alpha)$ sebesar 0,05 berarti Ha diterima dan Ho ditolak. Maka dapat disimpulkan bahwa bahwa ada hubungan secara signifikan antara Variabel Bebas terhadap Variabel Terikat.

4. Implementasi

a. Tanggapan konsumen terhadap krupuk kemplang (produk).

Produk $\left(\mathrm{X}_{2}\right)$ sebesar 0,345 berslope positif, hal ini menyatakan bahwa jika Kualitas Produk mengalami kenaikan sebesar 1 satuan, maka Keputusan Pembelian (Y) akan mengalami peningkatan sebesar 0,345. 
b. Tanggapan konsumen terhadap harga krupuk kemplang.

Harga $\left(\mathrm{X}_{1}\right)$ sebesar 0,289 berslope positif, hal ini menyatakan bahwa jika persepsi konsumen tentang Harga mengalami peningkatan sebesar 1 satuan, maka Keputusan Pembelian (Y) akan mengalami peningkatan sebesar 0,289 .

c. Kedekatan lokasi penjualan (toko/warung) mendorong konsumen untuk membeli.

Tempat/Distribusi $\left(\mathrm{X}_{3}\right)$ sebesar 0,342 berslope positif, hal ini menyatakan bahwa jika Tempat mengalami kenaikan sebesar 1 satuan, maka Keputusan Pembelian (Y) akan mengalami peningkatan sebesar 0,342 .

d. Promosi yang efektif menyebabkan konsumen tertarik untuk membeli ?

Promosi $\left(\mathrm{X}_{4}\right)$ sebesar 0,285 berslope positif, hal ini menyatakan bahwa jika Kualitas Promosi mengalami kenaikan sebesar 1 satuan, maka Keputusan Pembelian (Y) akan mengalami peningkatan sebesar 0,285.

e. Apakah keputusan pembelian oleh konsumen akan menciptakan pelanggan?

Nilai konstanta sebesar -1,040 menunjukkan bahwa jika Variabel Harga $\left(\mathrm{X}_{1}\right)$, Produk $\left(\mathrm{X}_{2}\right)$, Tempat

$\left(\mathrm{X}_{3}\right)$ dan Promosi $\left(\mathrm{X}_{4}\right)$ dianggap tidak ada (nol) maka Variabel Keputusan Pembelian (Y) sebesar 10,492 .

Solusi yang ditawarkan adalah pertama, strategi pengembangan produk bukan mengganti produk lama dengan produk baru, akan tetapi menambah banyaknya ragam bentuk produk yang dihasilkan. Kedua, promosi dan pemasaran produk selalu memperhatikan selera maupun kesukaan konsumen. Ketiga, peningkatan kualitas produk dan harga yang ditawarkan mampu bersaing.

\section{KESIMPULAN}

\subsection{Pembuat/penjual}

Pertama, faktor lingkungan internal dan eksternal pengelolah krupuk kemplang belum terstandarisasi dan belum mendukung. Kedua, strategi segmentasi pasar masih berskala usaha rumah tangga, dan pasar terpusat masih belum perlu, karena kalau dibuat pasar terpusat untuk produk ini, masih kurangnya (tidak stabil) pasokan untuk pembeli. Ketiga, pengembangan produk dan inovasi belum dilakukan, bentuk belum berani mereka ubah.

\subsection{Pembeli/konsumen}

Pertama, tanggapan konsumen terhadap krupuk kemplang (produk). Kualitas Produk berpengaruh terhadap peningkatan Keputusan Pembelian. Kedua, harga, kedekatan lokasi penjualan (toko/warung), promosi yang efektif menyebabkan konsumen tertarik untuk membeli.

\section{UCAPAN TERIMA KASIH}

Ucapan terimakasih diberikan kepada masyarakat pengusaha dan pembeli krupuk kemplang Desa Lumpatan. Karang taruna toko masyarakat dan pemerintah desa, kecamatan dan Kabupaten MUBA. Serta civitas akademi hingga pengabdian masyarakat ini terlaksana.

\section{DAFTAR PUSTAKA}

Adi, Isbandi, Rukminto. 2004. Pemberdayaan Pengembangan Masyarakat dan Investasi Komunitas, F.E. Universitas Indonesia. Jakarta.

Assauri, Sofyan. 2002. Manajemen Pemasaran dasar-dasar, Konsep dan strategi. Edisi Pertama, cetakan Ketujuh, Penerbit PT.Raja Grafindo Persada, Jakarta.

Peraturan Pemerintah Republik Indonesia Nomor 44 Tahun 1997 tentang kemitraan Masyarakat yang mempunyai usaha kreatif, berupaya melakukan pengembangan usaha kecilnya sehingga usaha kecil itu mampu menjadi usaha yang tangguh dan mandiri.

Sumarni, Murti. 2005. Metodologi Penelitian Bisnis. Andi Offset. Yogyakarta.

Tambunan. 2010. Perekonomian Indonesia. Edisi Ketiga. Yogyakarta:Penerbit BPFE.

Undang-undang Republik Indonesia. 1995. Tentang Perlindungan usaha kecil di Indonesia. 